\title{
The Processing Potentials of Yams (Dioscorea spp.) I. Laboratory Studies on Lye Peeling of Yams $^{1}$
}

\author{
W. J. C. Steele and G. M. Sammy ${ }^{2}$
}

\begin{abstract}
Six varieties from four species of yams (Dioscorea spp.) were studied. The use of $10 \%$ lye at $104^{\circ} \mathrm{C}$ with varying immersion times, depending on the variety, gave good results. Flesh losses were less for lye peeled than for "normal" hand peeled roots except in the case of Cush-cush. There was no free lye retention after peeling, nor did the heat treatment affect the cooking quality. It is concluded that yams can be lye peeled commercially.
\end{abstract}

\section{INTRODUCTION}

The tropical root-crop yam (Dioscorea spp.) is an important food crop in S.E. Asia, West Africa, South America and the Caribbean. It is a seasonal crop with a short ( 3 to 5 months) storage life $(1,2)$. Losses due to spoilage increase with increasing storage time and may range from 10 to $30 \%$.

Unlike white potato (Solanum tuberosum) (9) and sweet potato (Ipomoea batatas) $(4,5,6,8)$, yams have received little attention $(1,6)$ with respect to their processing potentials. If this crop is to play its full role in supplying the carbohydrate needs of people in the tropics, then some form of processing must be developed and used to extend its availability.

Commercial processing would depend on an economical peeling method. Mechanical peeling seems improbable at present because of the irregular shape and variable size of the tubers. However, chemical peeling seems to be a possibility as was demonstrated by Rivera-Ortíz and González (7).

\section{MATERIALS AND METHODS}

The yams studied were six varieties or cultivars from four species: $D$. alata-Lisbon, Oriental and Coconut; $D$. rotundata-Portuguese; $D$. trifida-White Cush-cush; and D. esculenta-Chinese. Their characteristics are given in table 1.

${ }^{1}$ Manuscript submitted to Editorial Board June 4, 1974.

${ }^{2}$ Graduate Assistant and Senior Lecturer, Department of Chemical Engineering, Faculty of Engineering, University of the West Indies, St. Augustine, Trinidad. 
T $\mathrm{ABLE}$ 1.-Characteristics of yam cultivars used in peeling trials

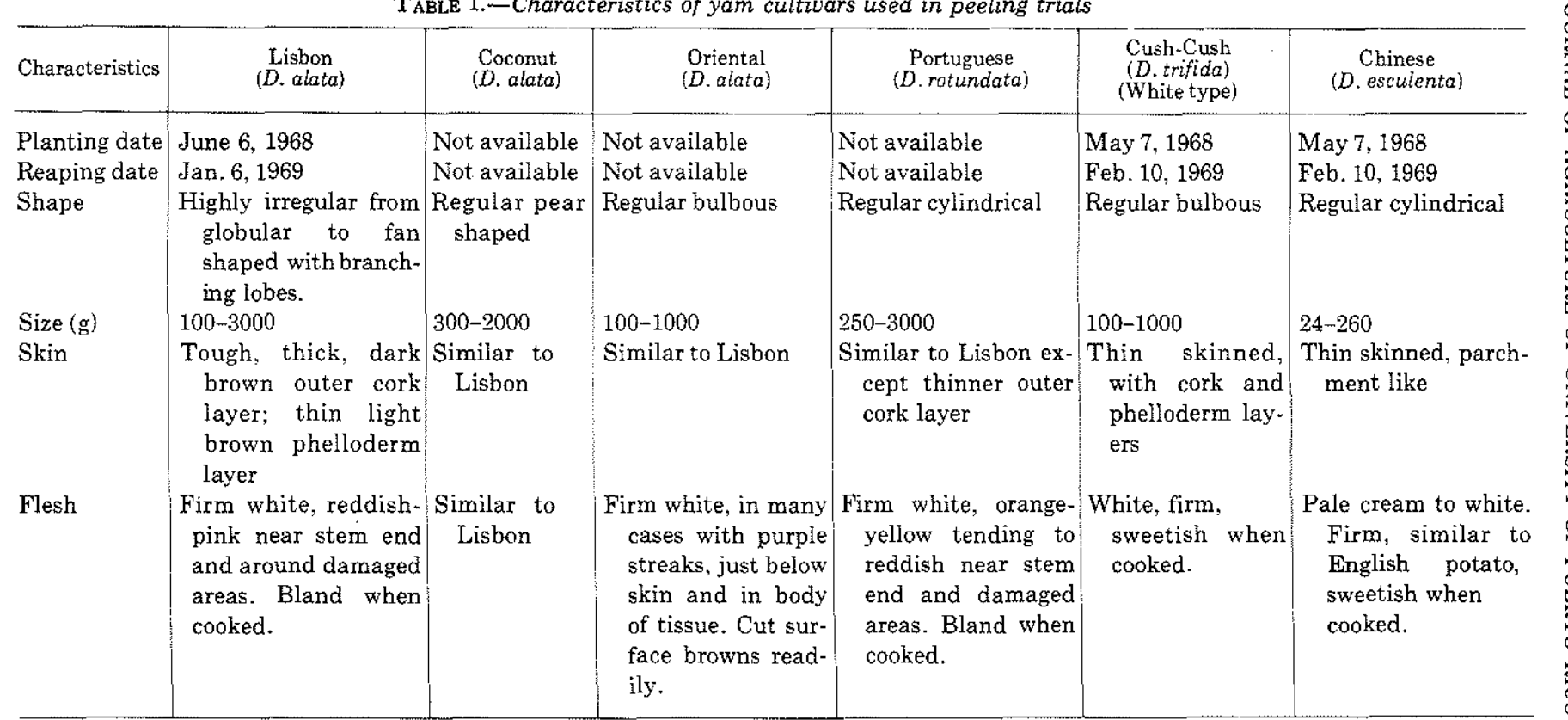


Lisbon, Cush-cush, Chinese and Oriental were obtained from the University Field Station at St. Augustine, Trinidad; Coconut, from Barbados; and Portuguese, from St. Vincent.

The sodium hydroxide used for making the lye solution was commercial (ICI) grade.

Hand peeling was used as the standard for comparison with lye peeling. Two types of hand peeling were performed: "careful" and

TABLE 2.-Immersion time, temperature, and concentration of lye for complete peeling performance

\begin{tabular}{|c|c|c|c|}
\hline \multirow{2}{*}{ Variety of yam } & \multicolumn{2}{|c|}{ Lye solution } & \multirow{2}{*}{ Immersion time } \\
\hline & Concentration & Temperature & \\
\hline & $\% w / v$ & ${ }^{\circ} \mathrm{C}$ & $\min$ \\
\hline Lisbon & 5.0 & 75 & 30 \\
\hline$"$ & 5.0 & 102 & 15 \\
\hline “ & 10.0 & 50 & 30 \\
\hline “" & 10.0 & 75 & 15 \\
\hline “" & 10.0 & 104 & 10 \\
\hline “ & 20.0 & 50 & 30 \\
\hline “" & 20.0 & 75 & 10 \\
\hline “ & 20.0 & 106 & 8 \\
\hline Portuguese & 5.0 & 75 & 30 \\
\hline a & 5.0 & 102 & 15 \\
\hline “ & 10.0 & 50 & 15 \\
\hline$" “$ & 10.0 & 75 & 10 \\
\hline “ & 10.0 & 104 & 8 \\
\hline “ & 20.0 & 50 & 10 \\
\hline “ & 20.0 & 75 & 5 \\
\hline “ & 20.0 & 106 & 2 \\
\hline Coconut & 5.0 & 102 & 15 \\
\hline " & 10.0 & 104 & 10 \\
\hline Oriental & 5.0 & 102 & 12 \\
\hline " & 10.0 & 104 & 10 \\
\hline Cush-Cush & 2.5 & 100 & 10 \\
\hline “ & 5.0 & 102 & 8 \\
\hline$،$ & 10.0 & 104 & 5 \\
\hline Chinese & 2.5 & 100 & 8 \\
\hline$"$ & 5.0 & 102 & 5 \\
\hline$"$ & 10.0 & 104 & 3 \\
\hline
\end{tabular}

"normal". Careful peeling consisted of a careful removal of the skin only (inedible portion) using a sharp knife; normal peeling always resulted in the inevitable removal of some edible flesh.

Clean yam tubers were immersed in lye solution of various concentrations $(2.5$ to $20 \% \mathrm{w} / \mathrm{v})$ and at different temperatures $\left(50^{\circ}\right.$ to $\left.106^{\circ} \mathrm{C}\right)$ for varying times ( 2 to $30 \mathrm{~min}$ ). They were then subjected to a spray of 
water under pressure $\left(30 \mathrm{lb} / \mathrm{in}^{2}\right)$ while gently but firmly brushing with a hard brush. "Complete" peeling was achieved when both the corky layer and phelloderm were readily and completely removed. Table 2 gives the conditions for lye peeling.

The appearance of "heat-rings" below the peeled surface was associated with lye peeling. These were easily recognised by the translucent appearance of a cross-section of the tuber as compared to the unaffected parts. Measurements of the heat-ring depth were made with calipers and rule.

Losses due to peeling were determined by difference. "True peel"

TABLE 3.-Changes in peeling performance of Lisbon yam with length of storage time

\begin{tabular}{|c|c|c|c|c|c|c|c|}
\hline \multirow{3}{*}{$\underset{\text { time }}{\text { Immersion }}$} & \multirow{3}{*}{$\begin{array}{l}\text { Section } \\
\text { of tuber }\end{array}$} & \multicolumn{6}{|c|}{ Peeling performance with $5 \%$ lye at $100^{\circ} \mathrm{C}$ and $10 \%$ lye at $104^{\circ} \mathrm{C}$} \\
\hline & & \multicolumn{2}{|c|}{ Freshly reaped } & \multicolumn{2}{|c|}{2 weeks storage } & \multicolumn{2}{|c|}{10 weeks storage } \\
\hline & & $5 \%$ Lye & $10 \%$ Lye & $5 \%$ Lye & $10 \%$ Lye & $5 \%$ Lye & $10 \%$ Lye \\
\hline \multicolumn{8}{|l|}{$\min$} \\
\hline \multirow[t]{2}{*}{1.0} & Stem & Nil & $\mathrm{Nil}$ & Nil & $\mathrm{Nil}$ & Nil & Nil \\
\hline & Rose & $\begin{array}{l}\text { Slightly } \\
\text { partial }\end{array}$ & $\begin{array}{l}\text { Slightly } \\
\text { partial }\end{array}$ & $\begin{array}{l}\text { Slightly } \\
\text { partial }\end{array}$ & $\begin{array}{l}\text { Slightly } \\
\text { partial }\end{array}$ & Nil & Nil \\
\hline \multirow[t]{2}{*}{2.5} & Stem & Partial $^{1}$ & Partial & Partial & Partial & \begin{tabular}{|} 
Slightly \\
partial
\end{tabular} & $\begin{array}{l}\text { Slightly } \\
\text { partial }\end{array}$ \\
\hline & Rose & $\begin{array}{l}\text { Almost } \\
\text { complete }\end{array}$ & $\begin{array}{l}\text { Almost } \\
\text { complete }\end{array}$ & $\begin{array}{c}\text { Almost } \\
\text { complete }\end{array}$ & $\mid \begin{array}{c}\text { Almost } \\
\text { complete }\end{array}$ & $\begin{array}{l}\text { Slightly } \\
\text { partial }\end{array}$ & $\begin{array}{l}\text { Slightly } \\
\text { partial }\end{array}$ \\
\hline \multirow[t]{2}{*}{5.0} & Stem & Partial & $\begin{array}{l}\text { Almost } \\
\text { partial }\end{array}$ & Partial & $\left|\begin{array}{c}\text { Almost } \\
\text { complete }\end{array}\right|$ & Partial & Partial \\
\hline & Rose & $\begin{array}{l}\text { Almost } \\
\text { complete }\end{array}$ & Complete $^{2}$ & 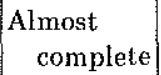 & Complete & Partial & Partial \\
\hline \multirow[t]{2}{*}{10.0} & Stem & & Complete & Complete & Complete & $\begin{array}{l}\text { Almost } \\
\text { complete }\end{array}$ & Complete \\
\hline & Rose & Excessive $^{3}$ & Excessive & $\begin{array}{l}\text { Slightly } \\
\text { excessive }\end{array}$ & Excessive & $\begin{array}{l}\text { Almost } \\
\text { complete }\end{array}$ & Complete \\
\hline
\end{tabular}

${ }^{1}$ Partial-removal of corky layer or partial removal of skin.

${ }^{2}$ Complete-removal of both corky layer and phelloderm.

${ }^{3}$ Excessive-significant amount of flesh removed on peeling.

weight (weight of inedible peel) was taken as the average of the careful peel weight.

The presence of free lye on the surface of the peeled washed yams was determined with phenolphthalein, universal indicator and $\mathrm{pH}$ meter. Sodium content was determined by flame photometry.

The rate of lye consumption in peeling was determined as follows: 41 of a $10 \%$ lye solution were prepared and checked by titration. This solution was brought to boiling and a fixed weight $(2 \mathrm{~kg})$ of yams was added. The liquid volume was noted after addition of the yams and the mixture boiled for $10 \mathrm{~min}$; volume loss due to evaporation was restored 
by the addition of water. Yams were then removed from the solution and drained for 5 min over the container containing the solution. Water was added to compensate for loss of volume due to entrainment, and change in concentration was determined by titration.

\section{RESULTS AND DISCUSSION}

Good results were obtained with a $10 \%$ solution at $104^{\circ} \mathrm{C}$ (bp of solution), but the immersion times varied with the different varieties. Lisbon and Coconut needed $10 \mathrm{~min}$; Portuguese and Oriental, $8 \mathrm{~min}$; Cush-cush needed only $5 \mathrm{~min}$. Chinese was peeled best (visual evaluation) in a $5 \%$ solution at $102^{\circ} \mathrm{C}$ for $5 \mathrm{~min}$.

TABLE 4.-Comparison of flesh losses between manual-and lye-peeled yams

\begin{tabular}{|c|c|c|c|c|c|}
\hline \multirow{3}{*}{ Variety } & \multirow{3}{*}{$\begin{array}{l}\text { Flesh loss in } \\
\text { "Ord" manual } \\
\text { peeling }\end{array}$} & \multicolumn{2}{|c|}{ Lye peeling conditions } & \multirow{2}{*}{\multicolumn{2}{|c|}{$\frac{\text { Flesh loss }{ }^{2} \text { in lye peeling }}{\text { Lye concentration }}$}} \\
\hline & & \multirow{2}{*}{ Time } & \multirow{2}{*}{ Temperature } & & \\
\hline & & & & $5 \%$ & $10 \%$ \\
\hline & $\%$ & $\min$ & ${ }^{\circ} \mathrm{C}$ & & \\
\hline Lisbon & 13 & 15 & 102 & 14.9 & \\
\hline “ & 13 & 10 & 104 & & 11.9 \\
\hline Coconut & 9.0 & 15 & 102 & 5.7 & \\
\hline “ & 9.0 & 10 & 104 & & \\
\hline Oriental & 9.4 & 10 & 102 & 9.2 & \\
\hline " & 9.4 & 7.5 & 104 & & \\
\hline Portuguese & 7.4 & 15 & 102 & 7.2 & \\
\hline " & 7.4 & 7.5 & 104 & & \\
\hline Cush-Cush & 10.3 & 7.5 & 102 & 12.3 & \\
\hline$"$ & 10.3 & 5 & 104 & & 11.8 \\
\hline Chinese & 8.0 & 5 & 102 & 2.1 & \\
\hline “" & 8.0 & 2.5 & 104 & & 5.8 \\
\hline
\end{tabular}

${ }^{1}$ Flesh loss was determined as the difference between careful manual peeling and ordinary manual or lye peeling.

Study of the peeling performance (table 3) shows a difference in peeling behaviour between: 1) The stem and rose end; and 2) the freshly reaped and the stored tubers. In a freshly reaped tuber, the rose end is more readily attacked; thus, complete peeling results in flesh losses at the rose end. On storage, the rose end hardens and a more uniform peeling results. Prolonged storage toughens the skin considerably, thus increasing immersion time for complete peeling.

Peeling losses of both hand and lye peeled yams increased with decreasing size of tuber (tables 4,5). Flesh losses for lye peeling were lower than normal hand peeling for all varieties studied except Cushcush, which was $2.0 \%$ higher. Peeling losses were lowest when $10 \%$ lye 
TABLE 5.-Comparison of peel losses of careful and ordinary manual with lye peeling 1

\begin{tabular}{|c|c|c|c|c|c|c|c|}
\hline \multirow{3}{*}{ Variety } & \multirow{3}{*}{ General shape } & \multirow{3}{*}{$\begin{array}{l}\text { Approx- } \\
\text { imate } \\
\text { number of } \\
\text { tubers } \\
\text { peeled }\end{array}$} & \multirow{3}{*}{$\begin{array}{c}\text { Average } \\
\text { weight } \\
\text { of each } \\
\text { tuber }\end{array}$} & \multicolumn{4}{|c|}{$\begin{array}{c}\text { Peel as percent of total } \\
\text { tuber }\end{array}$} \\
\hline & & & & \multirow[t]{2}{*}{ "C $\mathrm{C} " \mathrm{z}$} & \multirow[t]{2}{*}{ "N" } & \multicolumn{2}{|c|}{$\begin{array}{c}\text { Lye } \\
\text { concentration }\end{array}$} \\
\hline & & & & & & $5 \%$ & $10 \%$ \\
\hline & & & $g$ & & & & \\
\hline \multirow[t]{3}{*}{ Lisbon } & Globular & 15 & 330 & 16.0 & 28.5 & & \\
\hline & Cylindrical & 25 & 237 & 15.8 & 30.0 & & \\
\hline & $\begin{array}{l}\text { Fan-shaped with } \\
\text { lobes }\end{array}$ & 15 & 1520 & 11.8 & 25.2 & & \\
\hline Lisbon Average & & & & 14.5 & 27.9 & 28.8 & 25.8 \\
\hline Portuguese & Cylindrical & 10 & 779 & 10.2 & 17.6 & 17.2 & 15.0 \\
\hline Coconut & Oval & 10 & 1274 & 9.5 & 18.5 & 15.2 & 10.0 \\
\hline Oriental & Bulbous & 10 & 850 & 9.4 & 18.8 & 19.1 & 17.8 \\
\hline Cush-Cush & Bulbous & 10 & 187 & 9.0 & 19.0 & 19.3 & 18.8 \\
\hline Chinese & $\begin{array}{l}\text { (Mixed cyl/bulb/ } \\
\text { glob) }\end{array}$ & 50 & 54 & 9.8 & 17.0 & 11.9 & 15.6 \\
\hline
\end{tabular}

${ }^{1}$ Tubers were selected at random. The Portuguese, Coconut and Oriental had greater uniformity in shape and size than the Lisbon, Cush-Cush and Chinese. The weight spread for Lisbon was 160 to $2000 \mathrm{~g}$, Cush-cush 60 to $400 \mathrm{~g}$ and Chinese 24 to $200 \mathrm{~g}$.

2 "C" - carefully hand peeled.

s "N"-normal hand peeled.

TABLE 6.-Lye penetration in peeled tubers as determined by sodium content

\begin{tabular}{llcc}
\hline \multirow{2}{*}{ Variety } & Treatment & \multicolumn{2}{c}{ Sodium content } \\
\cline { 3 - 4 } & & $\begin{array}{c}\text { Outer } \\
\text { section }\end{array}$ & $\begin{array}{c}\text { Inner } \\
\text { section }\end{array}$ \\
\hline \multirow{2}{*}{ Lisbon } & Control (normal hand peeled) & 112 & $p / m$ \\
Cush-Cush & 10\% lye for 10 min & 227 & 108 \\
& Control & 69 & 119 \\
Chinese & 5\% lye for 10 min & 92 & 47 \\
& Control & 65 & 34 \\
\hline
\end{tabular}

TABLE 7.-Consumption of lye on repeated use of lye solution in peeling of Lisbon yams

\begin{tabular}{|c|c|c|c|c|}
\hline \multirow{2}{*}{ Batch } & \multirow{2}{*}{ Immersion time } & \multicolumn{2}{|c|}{ Lye concentration } & \multirow{2}{*}{$\begin{array}{c}\text { Change in } \\
\text { concentration }\end{array}$} \\
\hline & & Before peeling & After peeling & \\
\hline Number & $\min$ & \multicolumn{2}{|c|}{$\% w / v$} & $\%$ \\
\hline 0 & 0 & 10.00 & 10.00 & 0 \\
\hline 1 & 10 & 10.00 & 9.28 & 0.72 \\
\hline 2 & 10 & 10.10 & 9.42 & 0.68 \\
\hline 3 & 10 & 9.90 & 9.10 & 0.80 \\
\hline 4 & 10 & 10.05 & 9.35 & 0.70 \\
\hline 5 & 10 & 9.88 & 9.12 & 0.76 \\
\hline
\end{tabular}

${ }^{1}$ The average loss with each batch was $0.75 \%$ change in concentration. 
was used for all varieties except Chinese, which gave best results with $5 \%$.

The varieties Lisbon, Cush-cush and Chinese were tested for retention of lye in the tissues of the peeled tuber. No free lye was detected using phenolphthalein, universal indicator or $\mathrm{pH}$ meter; $\mathrm{pH}$ varied between 5.5 and 6.0. Examination for sodium using the flame photometer (table 6) showed an increase in the lye peeled tubers, but this was not significantly great. The greatest increase was $115 \mathrm{p} / \mathrm{m}$.

Lye consumption on repeated use of lye peeling solution is given in table 7 . There was an average loss of $0.75 \%$ sodium hydroxide with each batch of yams treated, or approximately $1 \mathrm{~g}$ sodium hydroxide per $60 \mathrm{~g}$ of yams treated. This compares favourably with lye consumption in the peeling of sweet potato, $1 \mathrm{~g} / 50 \mathrm{~g}$ (2). Repeated use darkens the lye solution and loads it with skin, root-hairs and other debris.

TABLE 8.-Effect of temperature and time on "heat-ring" depth

\begin{tabular}{|c|c|c|c|c|c|c|c|c|c|c|c|c|}
\hline $\begin{array}{l}\text { Immersion temperature }{ }^{\circ} \mathrm{C} \\
\text { and lye concentration }(\% \mathrm{w} / \mathrm{v}\end{array}$ & & $\begin{array}{l}100 \\
2.5\end{array}$ & & $\begin{array}{l}102 \\
5.0\end{array}$ & & & $\begin{array}{r}104 \\
10.0\end{array}$ & & & & $\begin{array}{r}106 \\
20.0\end{array}$ & \\
\hline Immersion time (min) & 2.57 & $7.5 \quad 10.0$ & 2.5 & 5.07 .5 & 15.0 & 1.02 .5 & 55.07 .5 & 10.0 & 1.0 & 2.5 & 3.0 & 5.010 .0 \\
\hline Variety & & & & Ave: & rage $h$ & heat-rin & g depth in & in $\mathrm{mm}$ & & & & \\
\hline Lisbon & & & 3 & & 12 & 3 & 35 & 15 & & 4 & & 819 \\
\hline Portuguese & & & 3 & & 12 & & 510 & & 3 & & 6 & \\
\hline Coconut & & & 4 & & 13 & & 6 & 15 & & & & \\
\hline Oriental & & & 3 & & 12 & 3 & 10 & & & & & \\
\hline Cush-cush & 2 & 10 & 4 & 8 & & 2 & 10 & & & & & \\
\hline Chinese & 51 & 15 & 5 & 12 & & $5 \quad 10$ & & & & & & \\
\hline
\end{tabular}

The heat-ring depth (table 8) varied directly with temperature and length of immersion time. The average depth of the heat rings for Lisbon, Portuguese, Coconut and Oriental was approximately the same for the same conditions of temperature and immersion times. However, Cush-cush and Chinese showed greater depth for corresponding temperatures and times. In spite of the translucent appearance of the affected areas they had neither a cooked taste, nor texture. This effect did not interfere with subsequent cooking of the yams.

Thus, results of laboratory experiments confirm the work of Rivera et al. (7), that yams can be lye peeled commercially.

\section{RESUMEN}

El ñame (Dioscorea spp.) constituye una importante fuente de alimento en las zonas tropicales del sureste de Asia, Africa Occidental, América del Sur y el Caribe. Como no se conserva bien en estado fresco por mucho tiempo, es necesario estudiar diversas maneras de conservarlo. Un aspecto importante para la industria conservera es desarrollar un método fácil y eficaz de pelar los tubérculos. 
Con este fin se estudiaron varias maneras de pelarlos: a mano con cuchillo y con lejía. En el estudio se incluyeron seis variedades de cuatro especies: alata, rotundata, trifida y esculenta.

El uso de lejía al 10 por 100 y a $104^{\circ} \mathrm{C}$. en varios períodos de inmersión dió buenos resultados, dependiendo de la variedad. La pérdida de pulpa fue menor cuando se pelaron con lejfa que cuando se pelaron a mano, excepto en el caso de la variedad Cush-cush (trifida). La pulpa no retuvo lejía libre después del pelado y el tratamiento con calor no afectó sus cualidades culinarias, por lo que puede concluirse que el ñame puede pelarse comercialmente con lejía.

\section{LITERATURE CITED}

1. Coursey, D. G., Yams. Trop. Agr. Ser, London. Longmans, Green and Co. Ltd., 1967.

2. González, M. A., and Collazo de Rivera, A., Storage of fresh yam (Dioscorea alata L.) under controlled conditions, J. Agr. Univ. P.R. 56 (1): 46-56, 1972.

3. Gooding, E. G. B., Private communication. Barbados Sugar Prod. Ass. Barbados, 1970.

4. Harris, H., and Barber, J. M., New uses for low grade sweet potatoes. Highlights Agr Res. Ala. 5 (3), 1958.

5. Hoover, M. V., and Pope, D. T., Factors influencing quality of sliced, precooked, frozen sweet potatoes, Food Technol. 13 (8): 448, 1959.

6. MacDonald, A. S., Sweet potatoes with particular reference to the Tropics. Field Crop Abstr. 14 (4): 219, 1963.

7. Rivera-Ortí, J. M, and González, M. A., Lye peeling of fresh yam, Dioscorea alata, J. Agr. Univ. P.R. 56(1): 57-63, 1972.

8. Sammy, G. M., Studies in composite flours. I. The use of sweet potato flour in bread and pastry making, Trop. Agr. Trin. 47 (2): 115, 1970.

9. Smith, Ora, and Davis, C. O., Potatoes: Production, Storing and Processing, The AVI Publishing Co. Inc., Westport, Conn., p. 558, 1968. 